\title{
KEMAMPUAN BERPIKIR KREATIF MATEMATIS SISWA MELALUI PROBLEM BASED LEARNING
}

\author{
Febriyani Putri ${ }^{1}$, M. Hasbi ${ }^{2}$ \\ ${ }^{1,2}$ Universitas Islam Negeri Sulthan Thaha Saifuddin Jambi \\ Email :febriyaniputri89@uinjambi.ac.id ${ }^{1}$ \\ hasbikarim04@uinjambi.ac.id ${ }^{2}$
}

\begin{abstract}
This research aimed at finding out (1)the improvement of the ability in creative mathematical thinking, (2) the improvement of the ability in reasoning and creative mathematical thinking for high, medium, and low level students. and (3) the interactions between students' preliminary ability and the learning approach in improving the reasoning and creative mathematical thinking. By involving PBL in learning requires students to think creatively to generate new ideas in learning. The design of the research was quasi experiment. The sample were the student of VIII.9 at SMPN 31 Padang and the students of VIII.1 at SMPN 25Padang. The result of the research showed that (1) the improvement of students' ability in creative mathematical thinking for those who were taught by using PBL was better than those who were taught by using the conventional learning, (2) the improvement of students' ability in creative mathematical thinking for the high, medium, and low level students who were taught by using PBL was better than those who were taught by using the conventional learning, and (3) there was interaction between the preliminary ability and the learning approach to students' creative mathematical thinking ability.
\end{abstract}

Keywords:creative mathematical thinking, problem based learning

\section{PENDAHULUAN}

Seringnya terjadi perubahan kurikulum terhadap pembelajaran yang pada awalnya berpusat pada guru dan pada akhirnya menjadi berpusat pada siswa, menutut siswa agar mampu mengembangkan kemampuan berpikir tingkat tingginya. Hal ini bertujuan agar siswa dapat bersaing baik ditingkat nasional maupun internasional. Pada pembelajaran matematika, kemampuan berpikir tingkat tinggi tersebut salah satunya adalah kemampuan berpikir kreatif matematis. Namun, nyatanya kemampuan berpikir kreatif pada saat pembelajaran jarang dilatih, sehingga kemampuan berpikir kreatif matematis belum berkembang secara maksimal dan berdampak pada kemampuan berpikir kreatif matematis siswa menjadi rendah. Hal ini terlihat dari gambaran proses pembelajaran. Pembelajaran matematika yang menekankan pada proses hafalan, siswa terbiasa menyelesaikan soal seperti yang dicontohkan oleh guru tanpa mencari alternatif jawaban lainnya terhadap soal-soal yang diberikan.

Berkaitan dengan pembelajaran, beberapa ahli seperti Rusman (2011), Ronis (2011), Permana dan Utari (2007), serta Howard dan Kelson dalam Amir (2010) mendefinisikan suatu pendekatan pembelajaran yang dapat membuat siswa lebih berpartisipasi aktif dalam pembelajaran dan memperoleh pengetahuan melalui penyajian masalah dengan konteks yang berkaitan dengan kehidupan nyata. Pembelajaran tersebut dinamakan Problem Based Learning yang dapat disingkat menjadi PBL. PBL merupakan pendekatan pembelajaran yang dirancang dengan masalah-masalah autentik atau masalah yang berkaitan dengan kehidupan nyata, sehingga siswa dapat mengembangkan pengetahuannya sendiri dalam menyelesaikan masalah berdasarkan pengalaman yang telah dialami.

Pembelajaran berbasis masalah sebagai suatu pendekatan yang memulai 
pembelajaran dengan suatu masalah yang harus diselesaikan oleh siswa dan pada akhirnya siswa mendapatkan konsep tentang materi yang dipelajari, dinilai mampu meningkatkan kemampuan berpikir kreatif matematis siswa. Pembelajaran berbasis masalah akan berlangsung dengan baik apabila mengikuti enam langkah kegiatan seperti yang dikemukakan oleh Sanjaya (2010), yaitu (1) mengidentifikasi masalah, (2) merumuskan masalah, (3) merumuskan hipotesis, (4) mengumpulkan data, (5) menguji hipotesis, dan (6) menentukan penyelesaian.

Langkah-langkah dalam PBL tersebut berbeda dengan pembelajaran konvensional. Pembelajaran konvensional adalah pembelajaran yang berorientasipada guru (teacher oriented), dimana hamper seluruh pembelajaran didominasi oleh guru. Pembelajaran konvensional memiliki ciri-ciri seperti yang dikemukakan Nasution (2005), diantaranya adalah (a) tujuan pembelajaran tidak dirumuskan secara spesifik; (b) bahan pelajaran diberikan kepada peserta didik tanpa memperhatikan peserta didik secara individual; (c) berorientasi pada kegiatan pendidik dan mengutamakan kegiatan mengajar; (d) peserta didik kebanyakan bersikap pasif mendengarkan uraian; dan (e) Pengajar umumnya sebagai penyebar atau penyalur informasi utama.

Pembelajaran konvensional memiliki perbedaan dengan PBL. Perbedaan yang paling utama terletak pada tahap penyajian masalah. Dalam PBL masalah disajikan pada awal pembelajaran yang mendorong siswa untuk menemukan konsep. Sedangkan pada pembelajaran konvensional, masalah diberikan pada akhir pembelajaran setelah guru menyampaikan materi pembelajaran. Oleh sebab itu PBL dipilih sebagai salah satu pendekatan pembelajaran yang dapat meningkatkan kemampuan berpikir kreatif matematis siswa. Perbedaan PBL dan pembelajaran konvensional dapat dilihat pada Tabel 1.

Tabel 1. Perbedaan PBL dengan Pembelajaran Konvensional

\begin{tabular}{|c|c|}
\hline Problem Based Learning & PembelajaranKonvensional \\
\hline $\begin{array}{l}\text { Masalah disajikan pada awal } \\
\text { pembelajaran, lebih ditekankan } \\
\text { untuk mengembangkan keterampilan } \\
\text { dari pada untuk menguji } \\
\text { keterampilan siswa }\end{array}$ & $\begin{array}{l}\text { Masalah disajikan pada akhir } \\
\text { pembelajaran setelah memahami } \\
\text { konsep, prinsip, dan keterampilan } \\
\text { matematika }\end{array}$ \\
\hline $\begin{array}{l}\text { Siswa membangun pengetahuan } \\
\text { sendiri }\end{array}$ & $\begin{array}{l}\text { Pengetahuan disampaikan dari guru } \\
\text { ke siswa }\end{array}$ \\
\hline $\begin{array}{l}\text { Siswa lebih terlihat secara aktif } \\
\text { mencari informasi }\end{array}$ & $\begin{array}{l}\text { Siswa menerima informasi secara } \\
\text { pasif }\end{array}$ \\
\hline $\begin{array}{l}\text { Belajar dan penilaian adalah hal yang } \\
\text { sangat terkait }\end{array}$ & $\begin{array}{l}\text { Belajar dan penilaian adalah hal yang } \\
\text { terpisah }\end{array}$ \\
\hline $\begin{array}{l}\text { Penekanan pada pengetahuan dalam } \\
\text { merefleksikan isu baru dan lama } \\
\text { serta menyelesaikan masalah dengan } \\
\text { konteks kehidupan nyata }\end{array}$ & $\begin{array}{l}\text { Penekanan pada pengetahuan di luar } \\
\text { konteks aplikasinya }\end{array}$ \\
\hline $\begin{array}{l}\text { Peran guru sebagai pendorong dan } \\
\text { pemberi fasilitas pembelajaran }\end{array}$ & $\begin{array}{l}\text { Peran guru sebagai pemberi } \\
\text { informasi dan penilai }\end{array}$ \\
\hline
\end{tabular}


Kemampuan berpikir kreatif matematis merupakan salah satu kemampuan dalam matematika yang harus dimiliki siswa. Kemampuan berpikir kreatif matematis adalah suatu kemampuan berpikir yang terkait dengan informasi baru atau ide-ide yang tidak biasa dalam menyelesaikan suatu masalah. Sabandar (2007) menyatakan bahwa berpikir kreatif adalah suatu kemampuan berpikir yang berawal dari adanya kepekaan terhadap situasi yang sedang dihadapi, bahwa situasi itu terlihat atau teridentifikasi adanya masalah yang ingin atau harus diselesaikan.

Pada kemampuan berpikir kreatif matematis, siswa dituntut untuk mampu menciptakan dan mengembangkan ideide baru yang dimilikinya serta mampu menyelesaikan masalah tidak hanya dengan menyelesaikannya dari satu sudut pandang saja.Oleh karena itu, dengan PBL siswa bebas untuk mengemukakan banyak ide dalam menyelesaikan masalah, sehingga kemampuan berpikir kreatif matematis siswa juga menjadi terlatih. Dari pernyataan tersebut mengisyaratkan bahwa kemampuan berpikir kreatif tidak hanya menuntut siswa untuk menciptakan ide-ide baru, tetapi juga siswa mampu menciptakan ide yang original atau asli dari dirinya sendiri dan berbeda dengan orang lain.

Pada dasarnya berpikir kreatif memiliki beberapa karakteristik, diantaranya adalah (1) kelancaran, (2) fleksibilitas, (3) orisinalitas, dan (4) elaborasi (Torrance dalam Filsaime, 2008). Kelancaran merupakan kemampuan untuk menciptakan segudang ide. Fleksibilitas merupakan kemampuan untuk menciptakan ide lain sebagai suatu alternative. Orisinalitas merupakan kemampuan untuk menciptakan ide yang tidak biasa dan unik sehingga berbeda dengan orang lain. Serta Elaborasi merupakan kemampuan untuk menguraikan suatu objek tertentu dengan sistematis dan lengkap. Keempat karakteristik tersebut memberikan pandangan tentang berpikir kreatif dan dapat membantu siswa menciptakan ide-ide baru dalam menyelesaikan masalah. Keempat karakteristik tersebut memberikan pandangan tentang berpikir kreatif dan dapat membantu siswa menciptakan ideide baru dalam menyelesaikan masalah.

Pada proses pembelajaran, kemampuan awal juga menjadi faktor yang mempengaruhi keberhasilan belajar siswa, karena kemampuan awal menggambarkan kesiapan siswa dalam menerima pembelajaran yang disampaikan guru. Kemampuan awal penting untuk diketahui guru, karena dapat meramalkan kesiapan siswa untuk mengikuti pembelajaran dengan materi baru.

Tujuan penelitian ini adalah untuk mengetahui (1) peningkatan kemampuan berpikir kreatif matematis siswa; (2) peningkatan kemampuan berpikir kreatif matematis siswa yang memiliki kemampuan awal tinggi, sedang, dan rendah.

\section{METODE PENELITIAN}

Penelitian ini merupakan penelitian eksperimen semu (quasi experiment) dengan rancangan penelitian Randomized Control Group Pre-testPosttest Design. Populasi pada penelitian ini adalah SMPN kota padang berlevel sedang sebanyak 25 sekolah. Teknik pengambilan sampel adalah Random Sampling. Sampel yang terpilih adalah siswa kelas VIII.9 SMPN 31 Padang sebanyak 23 orang siswa sebagai kelas eksperimen dan siswa kelas VIII.1 SMPN 25 Padang sebanyak 25 orang siswa sebagai kelas kontrol. Siswa kelas eksperimen diberikan pembelajaran 
PBL, sedangkan siswa kelas kontrol diberikan pembelajaran konvensional.

Instrumen yang digunakan dalam pengumpulan data adalah tes kemampuan awal yang digunakan untuk mengetahui kemampuan awal siswa, sehingga guru dapat mengetahui kesiapan siswa, selanjutnya siswa dibagi menjadi tiga kelompok kemampuan, yaitu kemampuan awal tinggi, sedang, dan rendah. Instrumen selanjutnya adalah tes berupa pre-test dan post-test untuk melihat peningkatan kemampuan berpikir kreatif matematis siswa.Pre-test dan post-test yang diberikan kepada siswa adalah soal yang memiliki level yang sama. Sebelum tes kemampuan awal serta pre-test dan post-test diberikan pada kelas sampel, terlebih dahulu dilakukan uji coba terhadap kedua tes tersebut. Uji coba tes tersebut dilakukan di SMPN 12 Padang. Hasil uji coba tes selanjutnya dilakukan analisis berupa: (1) analisis validitasbutirtes, (2) daya pembeda soal, (3) tingkat kesukaran soal, (4) kriteria penrimaan soal, dan (5) reliabilitas tes.

Teknik analisis data yang pertama dilakukan adalah dengan menghitung skorgain ternormalisasi. Gain ternormalisasi digunakan untuk menghitung besarnya peningkatan kemampuan berpikir kreatif matematis siswa. Untuk menghitung nilai gain ternormalisasi digunakan rumusberikut (Meltzer, 2002).

$g=\frac{\text { skorposttest }- \text { skorpretest }}{\text { skorideal }- \text { skorpretest }}$

Keterangan :

$g:$ gain ternormalisasi

Teknik analisis data yang digunakan selanjutnya adalah uji normalitas data, uji homogenitas variansi, dan uji hipotesis terhadap skor peningkatan kemampuan berpikir kreatif matematis. Pengujian hipotesis terhadap peningkatan berpikir kreatif matematis dilakukan dengan uji $t$ sedangkan pengujian terhadap interaksi antara kemampuan awal dan pendekatan pembelajaran dalam mempengaruhi berpikir kreatif matematis siswa dilakukan dengan menggunakan uji ANAVA dua arah. Semua pengujian statistik dilakukan dengan bantuan software SPSS.

\section{HASIL PENELITIAN DAN PEMBAHASAN \\ Kemampuan Awal}

Tes kemampuan awal merupakan tes yang berguna untuk mengukur kemampuan awal siswa. Dalam hal ini berupa pengetahuan matematika yang dimiliki oleh siswa yang berkaitan dengan materi yang akan dipelajari. Tes ini diberikan kepada siswa kelas eksperimen dan kelas kontrol pada awal pembelajaran sebelum masuk pada materi yang akan dipelajari.Setelah tes ini diberikan kepada siswa, selanjutnya hasil tes kemampuan awal tersebut dianalisis untuk mengelompokkan siswa berdasarkan kemampuan awalnya, yaitu siswa berkemampuan awal tinggi, sedang, dan rendah. Dari hasil analisis diperoleh bahwa siswaberkemampuan awal tinggi adalah siswa yang memiliki nilai $\geq 72,36$; siswa yang berkemampuan awal sedang adalah siswa yang memiliki nilai antara 32,94 dan 72,36; dan siswa berkemampuan awal rendah adalah siswa yang memiliki nilai $\leq 32,94$.

Berdasarkan kriteria tersebut, siswa kelas eksperimen dan kelas kontrol dikelompokkan berdasarkan kemampuan awalnya. Dari 23 orang siswa kelas eksperimen terdapat 5 siswa berkemampuan awal tinggi, 14 orang siswa berkemampuan awal sedang, dan 4 orang siswa berkemampuan awal rendah. Dari 25 orang siswa kelas kontrol 
terdapat 5 siswa berkemampuan awal tinggi, 17 orang siswa berkemampuan awal sedang, dan 3 orang siswa berkemampuan awal rendah.

\section{Peningkatan Kemampuan Berpikir Kreatif Matematis}

Besarnya nilai peningkatan kemampuan berpikir kreatif matematis siswa diperoleh dari hasil pre-test dan post-test dengan menghitung skor gain ternormalisasi. Rata-rata skor gain ternormalisasi menggambarkan rata-rata peningkatan kemampuan berpikir kreatif matematis siswa. Rata-rata peningkatan kemampuan berpikir kreatif matematis siswa dapat dilihat pada Tabel 2.

Tabel 2. Skor Peningkatan Kemampuan Berpikir Kreatif Matematis

\begin{tabular}{|c|c|c|c|c|c|c|c|c|c|}
\hline \multirow{2}{*}{ Kelas } & \multirow{2}{*}{ KA } & \multirow{2}{*}{$\mathbf{N}$} & \multicolumn{3}{|c|}{ Pre-test } & \multicolumn{3}{|c|}{ Post-test } & \multirow{2}{*}{$\overline{\boldsymbol{g}}$} \\
\hline & & & $\bar{x}$ & $s^{2}$ & $\boldsymbol{s}$ & $\bar{x}$ & $s^{2}$ & $s$ & \\
\hline \multirow{4}{*}{ Eksperimen } & Tinggi & 5 & 5,60 & 2,80 & 1,67 & 14,60 & 4,30 & 2,07 & 0,86 \\
\hline & Sedang & 14 & 4,21 & 2,64 & 1,63 & 11,79 & 8,95 & 2,99 & 0,63 \\
\hline & Rendah & 4 & 4,25 & 0,25 & 0,50 & 5,75 & 0,92 & 0,96 & 0,13 \\
\hline & Total & 23 & 4,52 & 2,44 & 1,56 & 11,35 & 14,42 & 3,80 & 0,59 \\
\hline \multirow{4}{*}{ Kontrol } & Tinggi & 5 & 6,60 & 1,30 & 1,14 & 11,40 & 0,80 & 0,89 & 0,51 \\
\hline & Sedang & 17 & 5,12 & 1,61 & 1,27 & 9,47 & 5,26 & 2,29 & 0,39 \\
\hline & Rendah & 3 & 5,33 & 0,33 & 0,58 & 9,00 & 1,00 & 1,00 & 0,34 \\
\hline & Total & 25 & 5,44 & 1,67 & 1,29 & 9,80 & 4,42 & 2,10 & 0,41 \\
\hline
\end{tabular}

Pada Tabel 2 terlihat bahwa ratarata skor pre-test kelas kontrol lebih tinggi daripada kelas eksperimen. Variansi dan simpangan baku skor pretest kelas eksperimen lebih tinggi daripada kelas kontrol. Rata-rata skor post-test siswa kelas eksperimen lebih tinggi daripada kelas kontrol. Variansi dan simpangan baku skor post-test kelas eksperimen lebih tinggi daripada kelas kontrol. Rata-rata skor peningkatan kemampuan berpikir kreatif matematis siswa kelas eksperimen yang diajar dengan PBL lebih tinggi daripada kelas kontrol yang diajar dengan pembelajaran konvensional. Dari segi kemampuan awal peningkatan kemampuan berpikir kreatif matematis siswa berkemampuan awal tinggi, sedang, dan rendah juga lebih tinggi daripada kelas kontrol.

Data kemampuan berpikir kreatif matematis siswa dianalisis secara statistik. Sebelum dilakukan uji hipotesis, terlebih dahulu dilakukan uji normalitas dan uji homogenitas variansi terhadap nilai gain ternormalisasi kelas eksperimen dan kelas kontrol. Hasil uji normalitas distribusi data peningkatan kemampuan berpikir kreatif matematis siswa kelas eksperimen dan kelas kontrol dapat dilihat pada Tabel 3.

Tabel 3. Hasil Uji Normalitas Peningkatan Kemampuan Berpikir Kreatif Matematis

\begin{tabular}{|c|c|c|}
\hline \multirow{2}{*}{$\begin{array}{c}\text { Kemam } \\
\text { puan } \\
\text { Awal }\end{array}$} & Kelas Eksperimen & Kelas Kontrol \\
\cline { 2 - 3 } & 0,560 & 0,757 \\
\hline Tinggi & 0,741 & 0,873 \\
\hline Sedang & 0,848 & 0,904 \\
\hline Rendah &
\end{tabular}


Pada Tabel 3 diperoleh nilai Sig. > taraf nyata $(\alpha=0,05)$, hal ini berarti bahwa $H_{0}$ diterima. Dengan demikian dapat disimpulkan bahwa data berdistribusi normal.
Hasil uji homogenitas variansi data peningkatan kemampuan berpikir kreatif matematis siswa kelas eksperimen dan kelas kontrol dapat dilihat pada Tabel 4.

Tabel 4. Hasil Uji Homogenitas Variansi Kemampuan Berpikir Kreatif Matematis

\begin{tabular}{|c|c|}
\hline Kemampuan Awal & Nilai Sig. Kelas Sampel \\
\hline Tinggi & 0,163 \\
\hline Sedang & 0,289 \\
\hline Rendah & 0,192 \\
\hline
\end{tabular}

Pada Tabel 4 diperoleh nilai Sig. > taraf nyata $(\alpha=0,05)$, hal ini berarti bahwa $H_{0}$ diterima. Dengan demikian dapat disimpulkan bahwa data memiliki variansi yang homogen. Pengujian hipotesis ini dilakukan dengan uji $t$. Hasil perhitungan uji hipotesis keenam dapat dilihat pada Tabel 5.

Tabel 5. Hasil Perhitungan Uji $t$ Peningkatan Kemampuan Berpikir Kreatif Matematis

\begin{tabular}{|c|c|c|c|c|}
\hline Kelas & N & Rata-rata & $\begin{array}{c}\text { Sig. } \\
(\text { 2-tailed) }\end{array}$ & $\begin{array}{c}\text { Sig. } \\
\text { (satu arah) }\end{array}$ \\
\cline { 1 - 3 } Eksperimen & 23 & 0,591 & \multirow{2}{*}{0,028} & 0,014 \\
\hline Kontrol & 25 & 0,408 & & \\
\hline
\end{tabular}

Pada Tabel 5, diperoleh bahwa peningkatan kemampuan berpikir kreatif matematis mempunyai nilai Sig. < taraf nyata $(\alpha=0,05)$ berarti tolak $H_{0}$. Dengan demikian dikatakan bahwa peningkatan kemampuan berpikir kreatif matematis siswa yang diajar dengan Problem Based Learning lebih baik daripada peningkatan kemampuan penalaran matematis siswa yang diajar dengan pembelajaran konvensional.

Uji interaksi antara kemampuan awal dan pendekatan pembelajaran dalam mempengaruhi peningkatan kemampuan berpikir kreatif matematis siswa. Pengujian hipotesis ini dilakukan dengan Analisis Variansi (ANAVA) dua arah. Hasil perhitungan uji hipotesis kesepuluh dapat dilihat pada Tabel 6.

Tabel 6. Hasil Interaksi antara Kemampuan Awal dan Pendekatan Pembelajaran dalam Mempengaruhi Peningkatan Kemampuan Berpikir Kreatif Matematis

\begin{tabular}{|c|c|c|c|c|c|}
\hline Source & $\begin{array}{c}\text { Type III Sum } \\
\text { of Squares }\end{array}$ & df & $\begin{array}{c}\text { Mean } \\
\text { Square }\end{array}$ & F & Sig. \\
\hline KA * Pendekatan & 0,357 & 2 & 0,179 & 3,662 & 0,034 \\
\hline Error & 2,048 & 42 & 0,049 & & \\
\hline
\end{tabular}

Pada Tabel 6, diperoleh bahwa nilai Sig. < taraf nyata $(\alpha=0,05)$ berarti tolak $\mathrm{H}_{0}$. Hal ini berarti bahwa terdapat interaksi antara kemampuan awal dan pendekatan pembelajaran dalam mempengaruhi peningkatan kemampuan berpikir kreatif matematis siswa. Kesimpulan ini juga dapat dilihat dengan grafik seperti pada Gambar 1. 
ISSN 2089-8703 (Print) Vol. 7, No. 1 (2018)

ISSN 2442-5419 (Online)

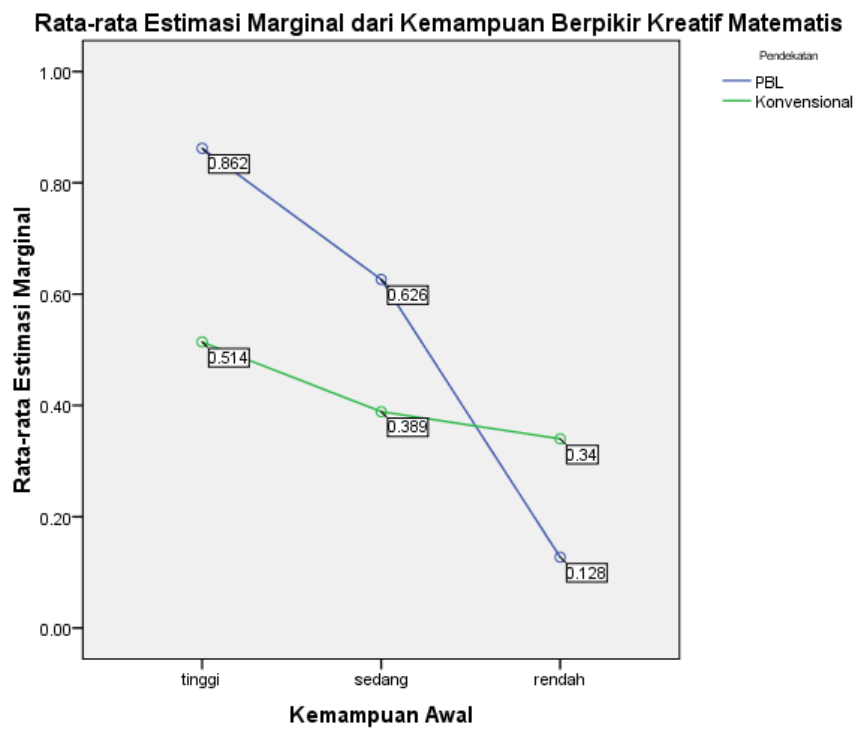

Gambar 1. Grafik Interaksi pada Kemampuan Berpikir Kreatif Matematis

Pada Gambar 1 terlihat bahwa garis pada grafik yang menunjukkan skor peningkatan kemampuan berpikir kreatif matematis siswa berkemampuan awal tinggi, sedang, dan rendah berpotongan disatu titik. Hal ini menunjukkan bahwa terdapat interaksi antara kemampuan awal dan pendekatan pembelajaran dalam mempengaruhi peningkatan kemampuan berpikir kreatif matematis siswa.

Karena terdapat interaksi antara kemampuan awal dengan pendekatan pembelajaran dalam mempengaruhi peningkatan kemampuan berpikir kreatif matematis siswa, maka dilakukan analisis lanjutan.

Tabel 7. Analisis Lanjutan

\begin{tabular}{|c|c|c|c|c|}
\hline & \multicolumn{2}{|c|}{ Pendekatan Pembelajaran } & \multirow{2}{*}{ Jumlah Baris } \\
\hline & & PBL & Konvensional & \\
\hline \multirow{3}{*}{$\begin{array}{c}\text { Kemam } \\
\text { puan } \\
\text { awal }\end{array}$} & Tinggi & $\begin{array}{l}\sum y=4,31 \\
\bar{y}=0,86\end{array}$ & $\begin{array}{l}\sum y=2,56 \\
\bar{y}=0,51\end{array}$ & $\begin{array}{l}\sum y=6,87 \\
\bar{y}=0,685\end{array}$ \\
\hline & Sedang & $\begin{array}{l}\sum y=8,76 \\
\bar{y}=0,63\end{array}$ & $\begin{array}{l}\sum y=6,60 \\
\bar{y}=0,39\end{array}$ & $\begin{array}{l}\sum y=15,36 \\
\bar{y}=0,51\end{array}$ \\
\hline & Rendah & $\begin{array}{l}\sum y=0,52 \\
\bar{y}=0,13\end{array}$ & $\begin{array}{l}\sum y=1,03 \\
\bar{y}=0,34\end{array}$ & $\begin{array}{l}\sum y=1,55 \\
\bar{y}=0,235\end{array}$ \\
\hline \multicolumn{2}{|c|}{ Jumlah Kolom } & $\begin{array}{l}\sum y=13,59 \\
\bar{y}=0,54\end{array}$ & $\begin{array}{l}\sum y=10,19 \\
\bar{y}=0,413\end{array}$ & $\begin{array}{l}\text { Total: } \\
\sum y=23,78 \\
\bar{y}=0,476\end{array}$ \\
\hline
\end{tabular}

Dari hasil analisis lanjutan diperoleh bahwa PBL lebih cocok diterapkan pada siswa yang memiliki kemampuan awal tinggi dan sedang, sedangkan pembelajaran konvensional lebih cocok diterapkan pada siswa yang memiliki kemampuan awal rendah saja.

Pembahasan

Selama pembelajaran dengan PBL berlangsung, siswa dapat menyelesaikan LKS dengan baik, ini karena banyak ide- 
ide yang dikemukakan oleh siswa, sehingga siswa tidak terlalu kesulitan untuk menentukan strategi penyelesaian masalah tersebut. Masalah-masalah yang diberikan adalah masalah terbuka yang berhubungan dengan kehidupan nyata yang dialami oleh siswa. Dengan demikian siswa juga dapat meningkatkan kemampuan berpikir kreatifnya, sehingga kemampuan berpikir kreatif matematis siswa yang diajar dengan PBL menjadi lebih baik dari pada siswa yang diajar dengan pembelajaran konvensional.

Berdasarkan hasil analisis data terhadap pengujian hipotesis statistik dengan uji $t$ pada taraf signifikansi $(0,05)$, ternyata peningkatan kemampuan berpikir kreatif matematis siswa baik secara keseluruhan maupun dari segi kemampuan awal yang dimiliki siswa mempunyai nilai Sig. yang lebih kecil dari taraf signifikansi $(0,05)$. Dengan demikian dapat disimpulkan bahwa peningkatan kemampuan berpikir kreatif matematis siswa yang diajar dengan PBL lebih baik daripada siswa yang diajar dengan pembelajaran konvensional.

\section{KESIMPULAN DAN SARAN Kesimpulan}

Berdasarkan hasil analisis data dan pembahasan, diperoleh kesimpulan bahwa (1) peningkatan kemampuan berpikir kreatif matematis siswa yang diajar dengan Problem Based Learning lebih baik dari pada siswa yang diajar dengan pembelajaran konvensional; (2) peningkatan kemampuan berpikir kreatif matematis siswa berkemampuan awal tinggi, sedang, dan rendah yang diajar dengan Problem Based Learning lebih baik dari pada siswa berkemampuan awal tinggi, sedang, dan rendah yang diajar dengan pembelajaran konvensional; (3) Terdapat interaksi antara kemampuan awal dan pendekatan pembelajaran dalam mempengaruhi peningkatan kemampuan berpikir kreatif matematis siswa.

\section{Saran}

Saran yang dapat dikemukakan setelah dilakukan penelitian ini, yaitu kepada guru matematika SMPN 31 Padang dan SMPN 25 Padang diharapkan dapat menerapkan PBL dalam pembelajaran, karena PBL dapat meningkatkan kemampuan berpikir tingkat tinggi siswa seperti kemampuan berpikir kreatif matematis siswa. Bagi peneliti lain yang tertarik untuk melalukan penelitian yang sama, agar menerapkan pendekatan Problem Based Learning untuk meneliti kemampuan matematis yang lain. Karena Problem Based Learning membutuhkan waktu yang cukup lama dan pengelolaan kelas yang baik, maka diharapkan untuk peneliti berikutnya dapat menggunakan waktu seefisien mungkin.

\section{DAFTAR PUSTAKA}

Amir, M. T. 2010. Inovasi Pendidikan melalui Problem Based Learning. Jakarta: Kencana

Filsaime, Dennis. K. 2008. Menguak Rahasia Berpikir Kritis dan Kreatif. Jakarta: PrestasiPustaka

Meltzer, D. E. 2002. The Relationship between Mathematics Preparation and Conceptual Learning Gains in Physics: A Possible "Hidden Variable" in Diagnostic Pre-test Score. Jurnal. Vol. 70, No. 12. Hal. $1259-1268$

Nasution, S. 2005. Berbagai Pendekatan dalam Proses Belajar dan Mengajar. Jakarta: Bumi Aksara.

Permana, Y dan Utari M. 2007. Mengembangkan Kemampuan Penalaran dan Koneksi Matematik Siswa SMA melalui Pembelajaran Berbasis 
ISSN 2089-8703 (Print) Vol. 7, No. 1 (2018)

ISSN 2442-5419 (Online)

Masalah. Jurnal. Vol. 1, No. 2, Hal. 116 - 123.

Ronis, D. 2001. Problem Based Learning for Math and Science Integrating Inquiry and the Internet. United States of America: Skylight Training and Publishing Inc

Rusman. 2011. Model-model Pembelajaran Mengembangkan Profesionalisme Guru. Jakarta: PT Raja Grafindo Persada

Sabandar, J. 2007. Berpikir Reflektif dalam Pembelajaran Matematika. Makalah disajikan dalam Seminar Nasional Matematika.Pascasarjana

Universitas Pendidikan Indonesia, Bandung, 8 Desember

Sanjaya, W. 2010. Strategi Pembelajaran Berorientasi Standar Proses Pendidikan. Jakarta: Kencana Persada Media 